\title{
Redevelopment Of Kampung Hindu in Kesawan Area, Medan With The Behavioral Architecture Approach
}

\author{
P. S. Pane* and D. N. Aulia \\ Departement of Architecture, Faculty of Engineering, Universitas Sumatera Utara, Medan, Indonesia \\ *email: putripane59@yahoo.co.id \\ Submitted: 12 January 2020 Revision: 22 January 2020 Online: 29 January 2020
}

\begin{abstract}
Based on Medan City Government 2012, slum areas in Medan City are currently estimated to reach $22.5 \%$ of the total area of Medan City, which consists of 88,166 housing units or $13.62 \%$ of the total houses in Medan City. Moreover, this has an impact on public health. Responding to this problem, the need to design a residence by rebuilding a residential area would be better by not abandoning the customs and culture of the people in the area. The project location is in Medan, Kampung Kelurahan Kesawan. The design method that is carried out is the choice of design location and approach to problem-solving design or design stages. It expects that the results of the design can provide suitable space and occupancy for the community, such as the construction of high-rise villages and community areas.
\end{abstract}

Keyword: Malay tribe, population density, stacking village

\section{INTRODUCTION}

The location of Kampung Hindu is behind Pasar Hindu and Masjid Bengkok. This village was famous in the period of Sultan Deli that settled a village and an empire near river banks. This proof can be seen at the village, whereas a Madrasah, a place for children to read Al-Quran and learn Islam, is still can be found. Sultan Deli bought Malay's tribe to their rule. Therefore, Malay tradition is the first tribe to be found near the Deli River.

The title of this project is Redevelopment of Hindu Village in Kesawan Area, Medan, with the Behavioral Architecture approach. This project is about arranging the settlement of a slump village by using it's own potential such as social, culture, and economy. The Heritage buildings which exist should get preserved so that the activity in this place and the culture will always revive.

Hindu street in Kesawan District is chosen to be the project location because it is one of the historical settlements in Medan. However, it eventually has a lack of attention from the government so that the activity in this area became less active, and the population densities made this area become a slump. Thus, this project focuses on how to design to rearrange this place into a better area so people that lived here can live peacefully from generation to generation.

This project's purpose is to design a comfortable and safe place to live for people in Hindu street, designing a building that is safe to live near the river, creating economy potential, especially to the locals, and creating an area that has heritage sustainable.

\section{Behavioral Architecture}

According to Oscar Levis in Suparlan (1984) due to the peak population density and the difficulty of finding work, the community had to build slum dwellings [1] After examining the issue in progress, an author is interested in implementing the Behavioral Architecture theme of this project. According to Notoatmodjo (2003), human behavior conceived by the activities of humans that observed directly and which could not be observed by humans outside [2].

While designing an occupancy, especially in stacking village projects, we must observe the behavioral of society. The human behavior sourced from biological traits and also from experience gained [3]. Human behavior patterns would be influenced and also affect the environment because the environment is a part 
of establishing a mindset [4]. Before designing, we must use the method of programming in approaching behavioral architecture, because of the programming is a process of setting the information available. So, the appropriate information could use as an output in designing [5].

So it can be concluded that activities and environment cannot be separated empirically. The architecture of Behavior is an art of design that can respond to all human needs and human feelings that adjust to the people's lifestyle.

The Patterns of Behavioral Architecture identical to human habits and local communities, such as reflecting the building function, accommodating the occupant's activities, observing the condition and the behavior of the users, this concept can be applying to prisons, school, settlement, and others. The building concept is where the communities can do daily activities in a new environment and have the same neighbor in a new residence. So, social ties are not separated and providing a more decent activity room.

\section{Culture, Social, Economy Condition}

In this area, the average population works as traders and laborers with low and medium incomes. The average traders sell small snacks, printings, and Padang-Nese's rice. Thus, many of them express bad habits by throwing garbage in the river and dry laundry in front of the entrance door area, in their house, which gives a poor vision to the facade. The Redevelopment aims to improve the environmental quality and the area so that residents of the settlements could stay in their place of origin [6].

The society that lasts long in this area is the Malay tribe that lived for decades. This village consists of adults that have busy pattern activities, and only a few of them like to gather and spend time along. However, besides having a bus time, they like to do social activities together on some occasions, such as cooperation and recitation of the Koran. In the afternoon, this village becomes crowded as the adults came back from work, and most of them spend time outside their house to socialize from one to another neighbor and their friends. Children are still playing old games like the boys who are still playing football (Figure 1). While ones that do not work, they gather to interact in the front house terrace and stairs in a mosque or madrasah ladders.

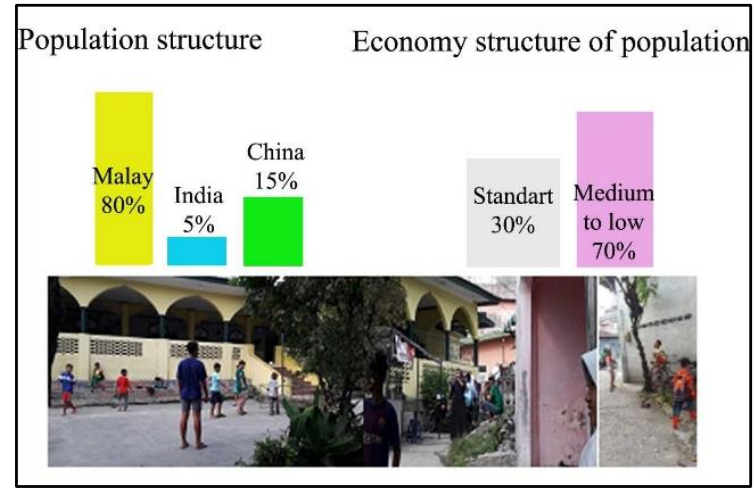

Figure 1. Various Activities such as Playing Football, Socializing, and Climbing Trees

\section{Malay}

Malay society has a characteristic such as a house on stilts with ornament, amenity, familiar with neighbors, help each other, gathering together, farming, and sell. As for culture such as a Malay dance, make a rhyme, music, and playing theatres. However, now the activities and culture that are related to Malay are rarely missed, because of busy working, and there is no public area to support those activities, so when afternoon only fulfilled with children, and when night this place is quiet, lonely and dark. As for the art culture, never seen any more, because there are no supporting facilities and areas. At this moment, the Kesawan area, there is no one to using a house on stilts because of changes in the times that make them think a house on stilts not required again, even though a house of stilts with ornaments is the main character from Malay community. The Malay's tribe have unique habits of pattern which they relate all activities to religions. They also have a robust social bond and happy in the world of arts such as music, dance, rhymes, poems, and theatre (Figure 2).

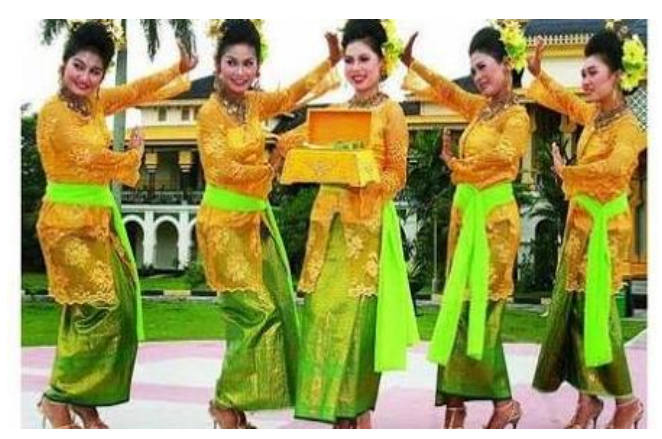

Figure 2. Malay's Dance 
(Source: kabar24.bisnis.com, Pusat

Kebudayaan Melayu Nusantara, accessed in February 2019)

\section{Rejuvenation Method}

This village renovation method is by analyzing the surrounding environment, by surveying and observing each activity and environment directly. From here, the problems arising include the slum of the environment, the culture that is almost gone, and the absence of open land for community activities. So that comes the solution including the provision of open land for socializing communities, including playing, gathering, and preserving Malay culture again, improvement of the river edge area so that it is not dirty anymore, provision of trade and social activities such as celebration, settlement of residential forms.

\section{METHODS}

The design process needs analysis of a design project which will do, such as physical analysis and nonphysical analysis. It obtained from the journal, book, internet, regulations, and comparative study. In this case, the author chooses the location in Medan exactly in Kesawan area as an object of design.

\section{Selection Method of Design Location}

Before the selection of the appropriate location, we must have two choices for comparison. The criteria for looking at a location are searching for a location that has a densely populated with an economic factor, searching for a cultural value which can make a village more active, design location reviewed by land area, and adjusted with the regulations. As for the location selected are Kampung Nelayan Belawan and Kampung Kelurahan Kesawan. Moreover, based on the survey, Kampung Kelurahan Kesawan is the most appropriate location

\section{RESULTS AND DISCUSSION}

\section{Analysis of Activities System and Space Program}

In the West Medan area, the project location located in the Kesawan village near the Hindu Market with a land area of 1.5 ha. There are 52 family heads in the project area, with 32 of them being poor people with an average number of children 2-4 children. Based on the analysis which gets from survey results, this occupancy consists of two types. Both types have different facilities. The following is the second space type program table with supporting facilities in residential areas. Moreover, this can be explained in (Tabel 1)

Table 1. Space Programming

\begin{tabular}{|c|c|c|c|c|c|c|c|}
\hline No & \begin{tabular}{|c} 
Room \\
Functi \\
on
\end{tabular} & $\begin{array}{l}\text { Room } \\
\text { Name }\end{array}$ & Total & $\mathbf{C p}$ & Dim & $\mid \begin{array}{c}\text { Area } \\
\left(\mathbf{m}^{2}\right)\end{array}$ & Source \\
\hline \multirow{6}{*}{1} & \multirow{6}{*}{$\begin{array}{l}\text { Room } \\
\text { Type } \\
36 \mathrm{~m}^{2}\end{array}$} & $\begin{array}{l}\text { Multipurpo } \\
\text { se room }\end{array}$ & 1 & - & 9 & 9 & $\mathrm{AD}$ \\
\hline & & Bedroom 1 & 1 & - & 9 & 9 & $\mathrm{AD}$ \\
\hline & & Bedroom 2 & 1 & - & 9 & 9 & $\mathrm{AD}$ \\
\hline & & Kitchen & 1 & - & 4 & 4 & $\mathrm{AD}$ \\
\hline & & Bathroom & 1 & - & 2,2 & 2,2 & $\mathrm{AD}$ \\
\hline & & \begin{tabular}{|l} 
Drying \\
Area
\end{tabular} & 1 & - & 3 & 3 & $\mathrm{AD}$ \\
\hline \multicolumn{6}{|c|}{ Total Area } & \multicolumn{2}{|c|}{$36,2 \mathrm{~m}^{2}$} \\
\hline \multicolumn{6}{|c|}{ Total Unit } & \multicolumn{2}{|c|}{34 unit } \\
\hline 2 & $\begin{array}{l}\text { Room } \\
\text { Type } \\
54 \mathrm{~m}^{2}\end{array}$ & $\begin{array}{l}\text { Main } \\
\text { Bedroom }\end{array}$ & 1 & - & 9 & 9 & $\mathrm{AD}$ \\
\hline & & Bedroom 1 & 1 & - & 9 & 9 & $\mathrm{AD}$ \\
\hline & & Bedroom 2 & 1 & - & 9 & 9 & $\mathrm{AD}$ \\
\hline & & $\begin{array}{l}\text { Living } \\
\text { Room }\end{array}$ & 1 & - & 9 & 9 & $\mathrm{AD}$ \\
\hline & & $\begin{array}{l}\text { Dining } \\
\text { Room }\end{array}$ & 1 & - & 9 & 9 & $\mathrm{AD}$ \\
\hline & & Kitchen & 1 & - & 4 & 4 & $\mathrm{AD}$ \\
\hline & & Bathroom & 1 & - & 2,2 & 2,2 & $\mathrm{AD}$ \\
\hline & & $\begin{array}{l}\text { Drying } \\
\text { Area }\end{array}$ & 1 & - & 3 & 3 & $\mathrm{AD}$ \\
\hline \multicolumn{6}{|c|}{ Total Area } & \multicolumn{2}{|c|}{$54,2 \mathrm{~m}^{2}$} \\
\hline \multicolumn{6}{|c|}{ Total Unit } & \multicolumn{2}{|c|}{24 unit } \\
\hline \multicolumn{8}{|c|}{ BUILDING FACILITIES } \\
\hline 3 & $\begin{array}{l}\text { Shared } \\
\text { Faciliti } \\
\text { es }\end{array}$ & Hall & 1 & 500 & $100 \mathrm{~m}^{2}$ & 500 & Asm \\
\hline 4 & $\begin{array}{l}\text { Comm } \\
\text { ercial } \\
\text { Faciliti } \\
\text { es }\end{array}$ & Shop & 10 & - & $\begin{array}{c}9 \\
\mathrm{~m}^{2} / \text { unit }\end{array}$ & & $B S N$ \\
\hline 5 & $\begin{array}{l}\text { Health } \\
\text { Faciliti } \\
\text { es }\end{array}$ & $\begin{array}{l}\text { Medical } \\
\text { Center }\end{array}$ & 1 & 40 & \begin{tabular}{|c|}
1,5 \\
$\mathrm{~m}^{2} /$ pers \\
on \\
\end{tabular} & 60 & $B S N$ \\
\hline \multirow[t]{3}{*}{6} & $\begin{array}{l}\text { Additio } \\
\text { nal } \\
\text { Faciliti } \\
\text { es }\end{array}$ & $\begin{array}{l}\text { The } \\
\text { Central } \\
\text { Area of } \\
\text { Learning } \\
\text { Malay } \\
\text { Culture }\end{array}$ & 2 & - & $289 \mathrm{~m}^{2}$ & 289 & Asm \\
\hline & & Garden & - & - & & & \\
\hline & & Playground & - & - & & & \\
\hline \multicolumn{6}{|c|}{ Total Area } & \multicolumn{2}{|c|}{$849 m^{2}$} \\
\hline \multicolumn{8}{|c|}{ SERVICE AREA } \\
\hline 7 & $\begin{array}{l}\text { Mecha } \\
\text { nical } \\
\text { Electri } \\
\text { cal }\end{array}$ & $\begin{array}{l}\text { Generator } \\
\text { Room }\end{array}$ & 1 & - & $20 \mathrm{~m}^{2}$ & 20 & SBT \\
\hline
\end{tabular}




\begin{tabular}{|c|c|c|c|c|c|c|c|}
\hline No & \begin{tabular}{|c} 
Room \\
Functi \\
on
\end{tabular} & $\begin{array}{l}\text { Room } \\
\text { Name }\end{array}$ & Tota & Cp & Dim & $\begin{array}{l}\text { Area } \\
\left(\mathbf{m}^{2}\right)\end{array}$ & Source \\
\hline & Room & & & & & & \\
\hline & & $\begin{array}{l}\text { Pump } \\
\text { Room }\end{array}$ & 1 & - & $20 \mathrm{~m}^{2}$ & 20 & SBT \\
\hline & & $\begin{array}{l}\text { Transforme } \\
\text { r Room }\end{array}$ & 1 & - & $15 \mathrm{~m}^{2}$ & 15 & SBT \\
\hline & & Panel & - & - & & & SBT \\
\hline 8 & $T P S$ & & - & - & $5 \mathrm{~m}^{2}$ & 10 & \\
\hline \multicolumn{6}{|c|}{ Total Area } & \multicolumn{2}{|c|}{$65 \mathrm{~m}^{2}$} \\
\hline \multirow[t]{4}{*}{9} & Office & \begin{tabular}{|l|} 
General \\
Manager's \\
Room
\end{tabular} & 1 & 1 & $\begin{array}{c}9 \\
\mathrm{~m}^{2} / \text { pers } \\
\text { on }\end{array}$ & 9 & $\mathrm{AD}$ \\
\hline & & $\begin{array}{l}\text { Employee's } \\
\text { Room }\end{array}$ & 1 & 4 & $\begin{array}{c}6 \\
\mathrm{~m}^{2} / \text { pers } \\
\text { on }\end{array}$ & 24 & $\mathrm{AD}$ \\
\hline & & $\begin{array}{l}\text { Informatio } \\
\text { n } \\
\text { Room/Wait } \\
\text { ing Room }\end{array}$ & 1 & 6 & $\begin{array}{c}2,4 \\
\mathrm{~m}^{2} / \mathrm{pers} \\
\text { on }\end{array}$ & 14,4 & $\mathrm{AD}$ \\
\hline & & Pantry & 1 & 8 & $\begin{array}{c}2,1 \\
\mathrm{~m}^{2} / \text { pers } \\
\text { on }\end{array}$ & 12,8 & $\mathrm{AD}$ \\
\hline 10 & Toilet & & 1 & 1 & $\begin{array}{c}3,2 \\
\mathrm{~m}^{2} / \text { pers } \\
\text { on }\end{array}$ & & \\
\hline
\end{tabular}

Based on the standards of the Department of Public Works, the total parking space for residential apartments is determined based on the number of families, namely one two-wheeled vehicle for every three families. However, one family has one or two vehicles, and with the number of visitors per house counted by one visitor. So the number of parking requirements in this building is 123 slots for two-wheeled vehicles.

\section{Analysis of Outdoor Space Design}

Based on the topography of Kampung Kelurahan, residential land has a sloping contour. The highest surface is in the west, and the lowest is at the riverbank (Figure 3). The prospect is that contours used as terracing and stairs, whose function is to anticipate floods and beautify the site, utilizing natural ventilation that flows from the river and provides recharge areas.

The design location is quite strategic because it located in the city center. The advantage is that the achievement is quite natural because of the large number of public transportation that passes and is close to other facilities and infrastructure.

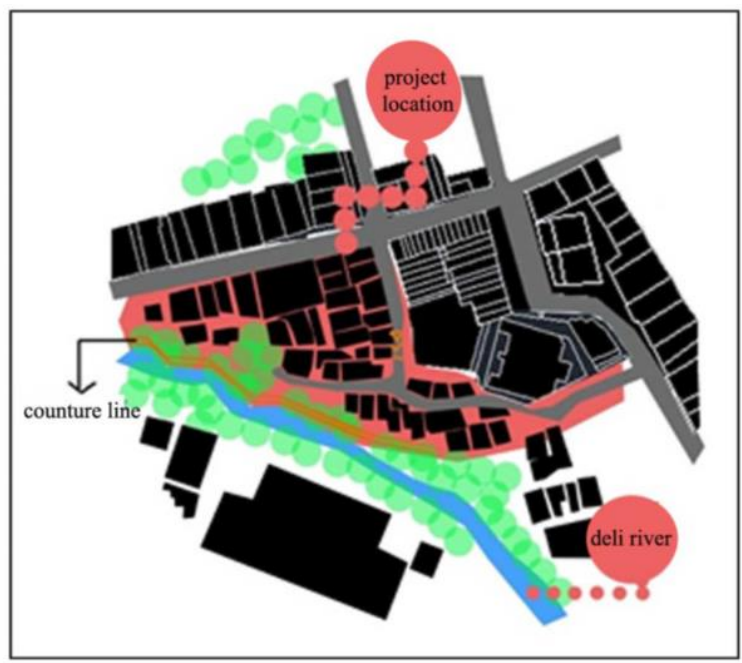

Figure 3. Conture Line in Project Location

The prospect is to establish a parking lot for visitors, pedestrians, and establish stops for visitors who come by public transportation (Figure 4). Furthermore, in the design location, pedestrians also built for pedestrians and disabled people so that the design is universal.

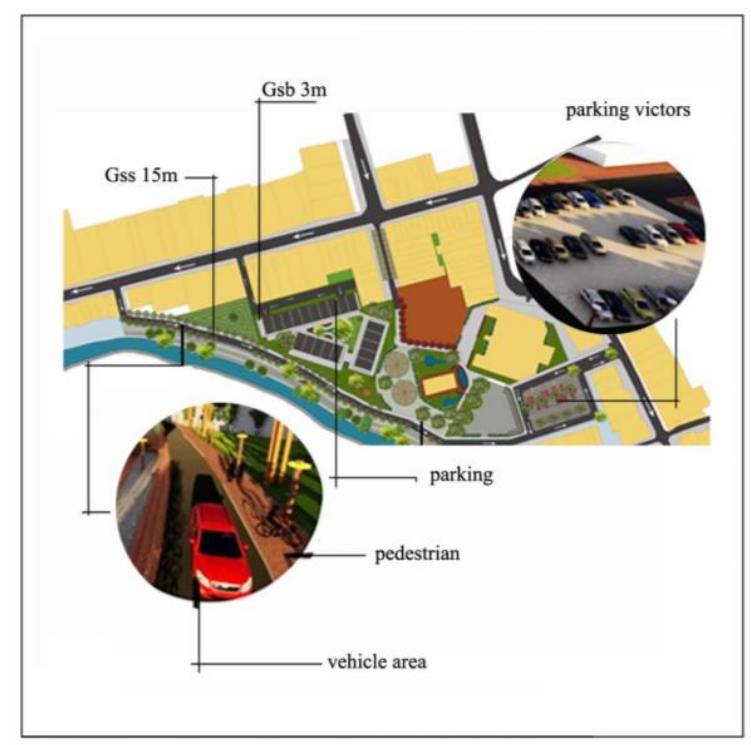

Figure 4. Parking Areas

\section{Concept}

This village design applies Architectural Behavior as its theme, which expected to fulfill and facilitate the community's habits. This site will become a mix-used area, which can increase the activity in the urban besides creating more attraction space the site, including the new pent-house building, which moving the slumps residents into a new place to 
live. There also has a central area at the bottom of dwelling, which used for cooking and culinary tours in the afternoon and the evening that is part of Pasar Hindu that developed by expanding the working hours. The facade of Pasar Hindu is maintained the same due to heritage conservation. This village providing facilities according to community behavior such as a vertical pent-house, shared outdoor, playing areas, outdoor sitting, and open space (Figure 5). The house design will be like a Malay house, which called a stage house where the bottom parts can prevent floods when heavy rains occur and trading centers during dry seasons. By that concept, this village expected to protect Malay's culture, so it is not extinct in the future.

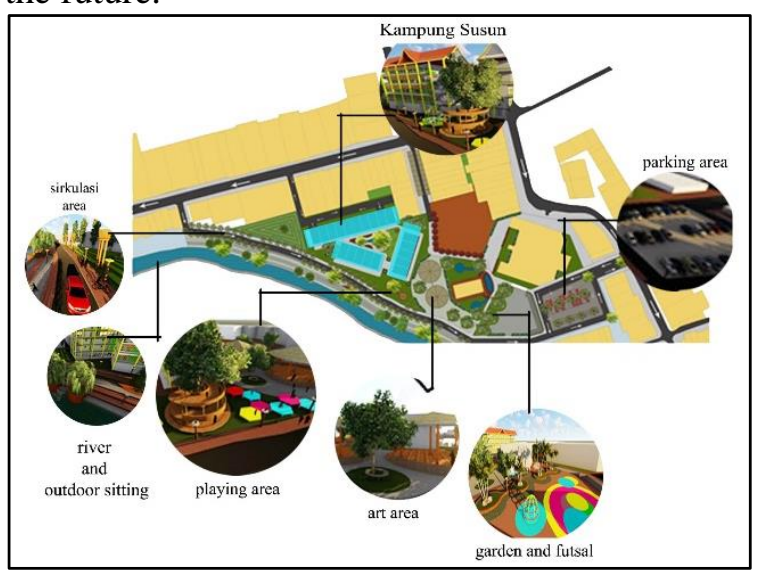

Figure 5. Various Activities such as Playing Football, Socializing, and Climbing Trees

Mass Formation, Site, Innerspace, and Facade Concept

Mass forming is following the site shape while the residential area designed face to face according to the previous residence pattern. This section is a play area and a treehouse for children (Figure 11).

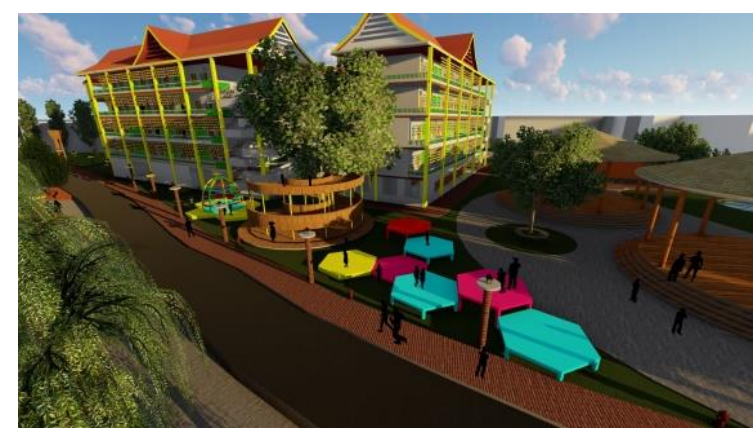

Figure 11. The Concept of Planting Trees Around The Road
This figure is the perspective image of the site location, where there are parking areas, parks, cultural areas, residential areas, gardens, and waterfronts (Figure 12).

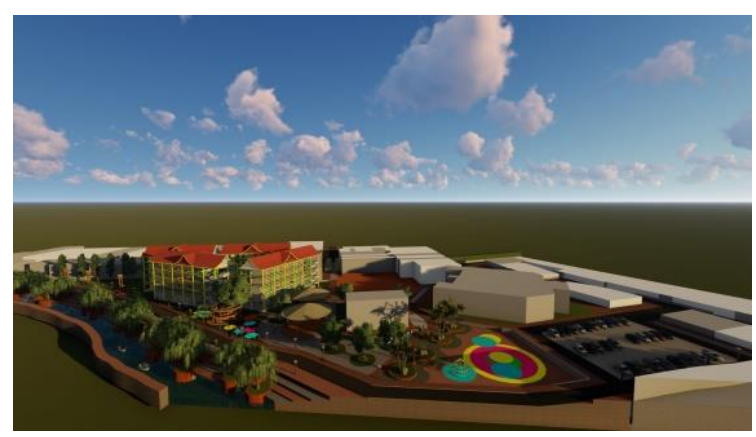

Figure 12. The Concept of Planting Trees Around The Road

It is an illustration of the children's playground and swung for Malay cultural areas (Figure 13).

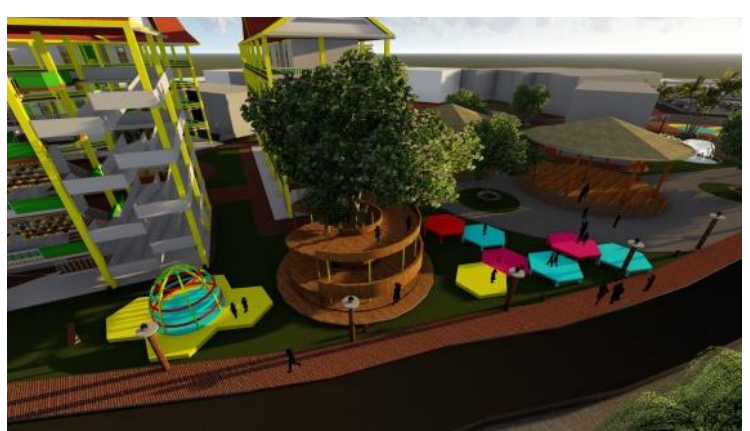

Figure 13. The Concept of Planting Trees Around The Road

The scenery of the road in the residential area, where the river becomes a waterfront area, and across the road is a garden to water plants (Figure 14).

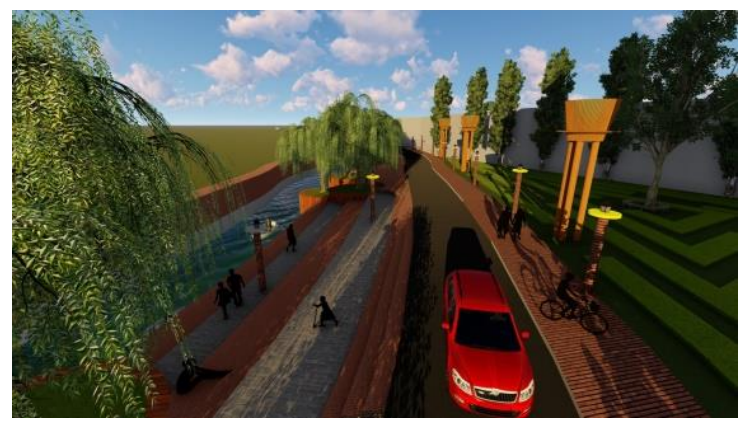

Figure 14. The Concept of Planting Trees Around The Road 

The facade of the building looks like a Malay house, which has a stage where the lower part functions as a retail/market area. Then the column is yellow with a decorative ornament, then use a vertical garden that uses a bottle as a plant container, where bottles are painted yellow, identical to Malay colors. Where on the fence part of the building, each floor uses the previously used house material, which shows in (Figure 15).

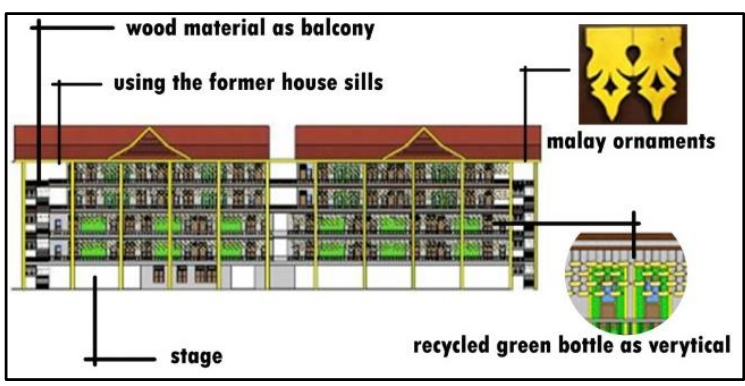

Figure 15. Facade Concept

\section{Basic Concept in Application}
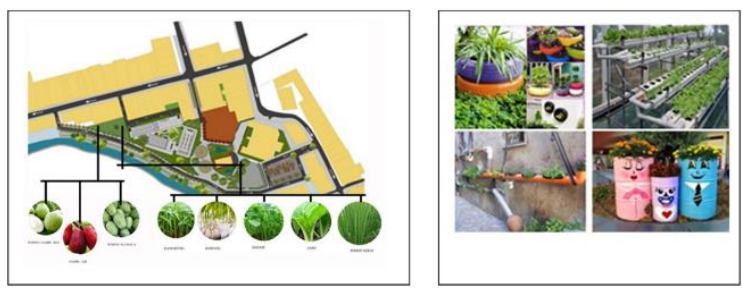

Figure 16. Urban Farming

The residential area divided into three areas there are a residential area, retail, and service area. The residential area placed at the top level so that the occupants were not disturbed, and the room is not flooding. The retail and service area places at the ground and the traders moved to better and neater areas (Figure 17).

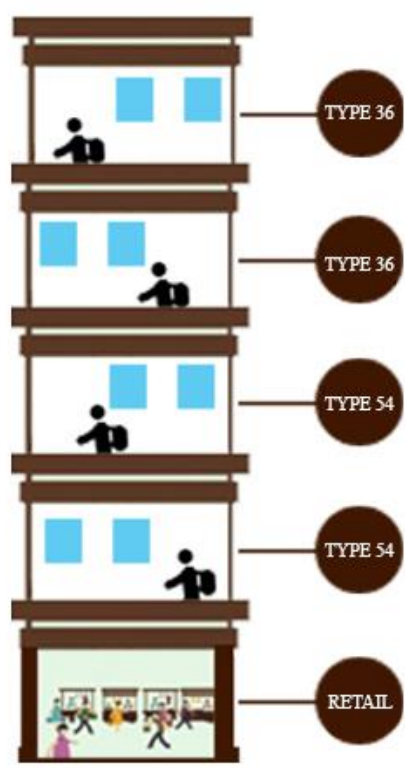

Figure 17. Vertical Zoning

\section{CONCLUSION}

After making an investigation and observation, the conclusion is that the location project is suitable and needed to be revitalizing with an application of behavior architecture. This act is made to ensure that this area and the Malay tribe that lived in this place through the decades can pass their culture and buildings assets to their children and heritage still exist through building conservation.

This project focuses on how to make and area of the excellent neighborhood without erasing its social aspect. The solution to all problems in this area is by designing new facilities and accommodations such as pedestrian walk by the river, children's playground, farming area, developmental stage, and making the base of central building a market as social interactions and needs.

\section{ACKNOWLEDGMENT}

This article is written by researchers who are partly funded by the Universitas Sumatera Utara and was given out as a donation to the government to preserve and improve the value of design, local wisdom, arts, and ethnic. 



\section{REFERENCES}

[1] O. Lewis, "Kebudayaan kemiskinan," Kemiskinan di Perkotaan. Jakarta: Yayasan Obor Indonesia, 1993.

[2] S. Notoadmojo, Pendidikan dan perilaku kesehatan, Jakarta: Jakarta: Rineka Cipta, 2003.

[3] J. Laurens, Arsitektur dan Perilaku Manusia, Jakarta: Grasindo, 2004.

[4] G. Moore, Architectural programming: Information management for design, Wiley, 1993.

[5] D. P. Duerk, Architectural programming: Information management for design, Wiley, 1993.

[6] W. P. Barada, "Analisis Space Syntax Rumah Susun Berbasis Gang Kampung," in Simposium Nasional RAPI XII, Surakarta, 2013. 